\title{
DNA Footprinting
}

National Cancer Institute

\section{Source}

National Cancer Institute. DNA Footprinting. NCI Thesaurus. Code C17890.

A procedure that determines the sequence specificity for DNA binding proteins. Target DNA is end-labeled and exposed to the protein of interest. The sample is then treated with a DNA damaging agent that cleaves at random base pairs. Protein-bound DNA is protected from the cleavage and can be analyzed by gel electrophoresis. 